Article

\title{
Phenolic Compounds from the Roots of Rhodiola crenulata and Their Antioxidant and Inducing IFN- $\gamma$ Production Activities
}

\author{
Jiang-Tao Zhou ${ }^{1,2, \dagger}$, Chen-Yang Li ${ }^{3, \dagger}$, Chun-Hua Wang ${ }^{1,2, *}$, Yue-Fei Wang ${ }^{1}$, \\ Xiao-Dong Wang ${ }^{3}$, Hong-Tao Wang ${ }^{4}$, Yan Zhu ${ }^{1,2}$, Miao-Miao Jiang ${ }^{1,2, *}$ and Xiu-Mei Gao ${ }^{1}$
}

1 Tianjin Key Laboratory of Modern Chinese Medicine, Tianjin University of Traditional Chinese Medicine, Tianjin 300193, China; E-Mails: zjt19881206@126.com (J.-T.Z.); pharmwch@126.com (C.-H.W.); 13516185421@139.com (Y.-F.W.); yanzhu.harvard@gmail.com (Y.Z.); gaoxiumei@tjutcm.edu.cn (X.-M.G.)

2 Research and Development Center of Traditional Chinese Medicine, Tianjin International Joint Academy of Biotechnology \& Medicine, Tianjin 300457, China

3 Department of Pharmacy, School of Medicine, Shenzhen University, Shenzhen 518060, China; E-Mails: lichenyangchina@163.com (C.-Y.L.); wangxiaodong@szu.edu.cn (X.-D.W.)

4 Shijiazhuang Yiling Pharmaceutical Co., Ltd, Shijiazhuang 050035, China; E-Mail:wht72007@126.com

$\dagger$ The authors contributed equally to this work.

* Authors to whom correspondence should be addressed; E-Mails: pharmwch@126.com (C.-H.W.); miaomiaojiang@126.com (M.-M.J.); Tel.: +86-222-738-6453 (C.-H.W.); +86-222-738-6453 (M.-M.J.).

Academic Editors: Luis Cisneros-Zevallos and Daniel Jacobo-Velazquez Received: 30 June 2015 / Accepted: 23 July 2015 / Published: 28 July 2015

\begin{abstract}
In the present study, two new phenolic compounds 1 and 11, a pair of lignan isomers $\mathbf{1 2}$ and $\mathbf{1 3}$ with their absolute configurations established for the first time, were isolated from the ethanol extract of the roots of Rhodiola crenulata, together with 13 known phenolic compounds, and their structures were elucidated via NMR, HRESIMS, UV, IR and $\mathrm{CD}$ analyses. All the isolated compounds were evaluated for their in vitro antioxidant activities using the 2,2-diphenyl-1-picryhydrazyl (DPPH) and 2,2'-azino-bis (3-ethylbenzothiazoline6-sulfonic acid) (ABTS) radical scavenging assays. Ten of them exhibited significant antioxidant activities compared to ascorbic acid. Furthermore, the inducibilities of the isolated compounds to IFN- $\gamma$ production were also assessed. Compounds $1,8,9,12,13,14$ and 15 could moderately stimulate IFN- $\gamma$ expression.
\end{abstract}


Keywords: Rhodiola crenulata; phenol; antioxidant activity; IFN- $\gamma$ production; immunomodulatory effect

\section{Introduction}

Rhodiola crenulata (HK. f. et.Thoms) H. Ohba (Dhua Hong-Jing-Tian in Chinese) is an important species among the Rhodiola genus, mainly found distributed in western regions of China including the provinces of Yunnan, Sichuan and Tibet [1]. As a functional food, $R$. crenulata is used for prevention against high-altitude illness and regarded by the tourists going to plateau as a traditional phyto-adaptogen to environmental challenges [2]. Moreover, the extracts of $R$. crenulata have been made into pharmaceutical preparations and cosmetics with varied bioactivities [3,4]. Due to its extensive application in food, medicine and cosmetics, the chemical constituents and pharmacological activities of $R$. crenulata have been widely investigated. The main chemical constituents of $R$. crenulata are phenolic compounds, such as flavonoids, phenylpropanoids, phenolic acids and so on [5-10]. Modern pharmacological investigations have revealed that Rhodiola preparations exhibit antioxidant, immunomodulatory, anti-aging, anti-fatigue [11,12], neuroprotective [13], anti-inflammatory [14], antidepressive, anxiolytic, nootropic, life-span increasing and central nervous system (CNS) stimulating activities [15]. Due to the diverse biological activities of $R$. crenulata, the chemical constituents of $R$. crenulata and the bioactivities of the isolates were investigated by our research group.

\section{Results and Discussion}

\subsection{Identification of Compounds $\mathbf{1}-\mathbf{1 7}$}

Compound 1 was isolated as a light yellow solid. Its molecular formula was determined as $\mathrm{C}_{17} \mathrm{H}_{22} \mathrm{O}_{6}$ by HRESIMS $[\mathrm{M}-\mathrm{H}]^{-}$at $m / z$ 321.1338, (calcd, for $\mathrm{C}_{17} \mathrm{H}_{21} \mathrm{O}_{6}, 321.1338$ ). The IR spectrum displayed $\mathrm{OH}\left(3411 \mathrm{~cm}^{-1}\right), \mathrm{C}=\mathrm{O}\left(1708\right.$ and $\left.1734 \mathrm{~cm}^{-1}\right)$, and $\mathrm{C}=\mathrm{C}\left(1633 \mathrm{~cm}^{-1}\right)$ functions. The ${ }^{1} \mathrm{H}-\mathrm{NMR}$ spectrum revealed the existence of five methylenes at $\delta_{\mathrm{H}} 4.12(2 \mathrm{H}, \mathrm{t}, J=6.6 \mathrm{~Hz}), 2.33(2 \mathrm{H}, \mathrm{t}, J=7.4 \mathrm{~Hz}), 1.64(2 \mathrm{H}$, $\mathrm{m}), 1.58(2 \mathrm{H}, \mathrm{m})$ and $1.37(2 \mathrm{H}, \mathrm{m})$, an $\mathrm{ABX}$ aromatic protons at $\delta \mathrm{H} 7.33(1 \mathrm{H}, \mathrm{d}, J=2.0 \mathrm{~Hz}), 7.12(1 \mathrm{H}$, $\mathrm{dd}, J=8.2,2.0 \mathrm{~Hz})$ and $6.80(1 \mathrm{H}, \mathrm{d}, J=8.2 \mathrm{~Hz})$, and two methoxyls at $\delta \mathrm{H} 3.83$ and 3.59. The signals at $\delta_{\mathrm{H}} 7.55(1 \mathrm{H}, \mathrm{d}, J=16.0 \mathrm{~Hz})$ and $6.47(1 \mathrm{H}, \mathrm{d}, J=16.0 \mathrm{~Hz})$ suggested trans double bond protons. The ${ }^{13} \mathrm{C}-\mathrm{NMR}$ spectrum revealed the presence of $17 \mathrm{C}$-atoms, which were identified with DEPT-135 spectrum as five methylenes $\left(\delta_{\mathrm{C}} 63.5,33.1,27.9,25.0\right.$ and 24.1$)$, two methoxyls $\left(\delta_{\mathrm{C}} 55.7\right.$ and 51.2$)$, two carbonyl groups ( $\delta \mathrm{c} 173.3$ and 166.7), as well as a pair of olefinic carbons with trans double bond features $\left(\delta_{\mathrm{c}} 145.0\right.$ and 114.4$)$. The chemical shifts from $\delta_{\mathrm{c}} 111.2$ to 149.5 were in the aromatic region, which indicated a benzene ring and a double bond existed. From the above NMR data (Table 1), a 3,4-disubstituted cinnamoyl group linked with a fatty alcohol was deduced. Thus, the chemical structure illustrated in Figure 1 were established on the basis of these data. This was further confirmed by the key $\mathrm{HMBC}$ correlations (Figure 2) from $\delta_{\mathrm{H}} 3.59\left(\mathrm{OCH}_{3}\right)$ to $173.3\left(\mathrm{C}-1^{\prime}\right)$, from $\delta_{\mathrm{H}} 4.12\left(\mathrm{H}-6^{\prime}\right)$ to $\delta_{\mathrm{C}} 166.7$ (C-9) and 27.9 (C-5). So, compound 1 was determined as methyl 6-O-(3-methoxy-4-hydroxy-cinnamoyl)caproate and named rhodiolate. 
Table 1. ${ }^{1} \mathrm{H}-\mathrm{NMR}$ and ${ }^{13} \mathrm{C}-\mathrm{NMR}$ data of compounds 1, 2 and 11-13 (400 MHz and $100 \mathrm{MHz}$, DMSO-d6, $\delta$ in ppm, $J$ in Hz).

\begin{tabular}{|c|c|c|c|c|c|c|c|c|c|c|}
\hline \multirow{2}{*}{ No. } & \multicolumn{2}{|l|}{1} & \multicolumn{2}{|l|}{2} & \multicolumn{2}{|l|}{11} & \multicolumn{2}{|l|}{12} & \multicolumn{2}{|l|}{13} \\
\hline & $\delta_{H}$ & $\delta_{\mathrm{C}}$ & $\boldsymbol{\delta}_{\mathrm{H}}$ & $\boldsymbol{\delta}_{\mathrm{C}}$ & $\boldsymbol{\delta}_{\mathrm{H}}$ & $\boldsymbol{\delta}_{\mathrm{C}}$ & $\delta_{H}$ & $\delta_{C}$ & $\boldsymbol{\delta}_{\mathrm{H}}$ & $\boldsymbol{\delta}_{\mathrm{C}}$ \\
\hline 1 & & 125.5 & & & & 131.8 & & 127.7 & & 127.6 \\
\hline 2 & $7.33(\mathrm{~d}, 2.0)$ & 111.2 & & 147.6 & $6.79(\mathrm{~d}, 1.2)$ & 114.0 & $7.01(\mathrm{~d}, 1.8)$ & 112.2 & 7.07 (s) & 112.2 \\
\hline 3 & & 149.5 & & 135.9 & & 147.4 & & 148.1 & & 148.3 \\
\hline 4 & & 148.0 & & 176.9 & & 145.4 & & 147.6 & & 147.9 \\
\hline 5 & $6.80(\mathrm{~d}, 8.2)$ & 115.5 & & 152.7 & $6.74^{\mathrm{a}}$ & 115.8 & $6.80(\mathrm{~d}, 8.0)$ & 115.8 & $6.84^{\mathrm{a}}$ & 115.5 \\
\hline 6 & $7.12(\mathrm{dd}, 8.2,2.0)$ & 123.1 & $6.56(\mathrm{~s})$ & 95.4 & $6.64(\mathrm{dd}, 8.2,1.8)$ & 117.3 & $6.85(\mathrm{dd}, 8.0,1.8)$ & 121.0 & $6.85^{\mathrm{a}}$ & 120.0 \\
\hline 7 & $7.55(\mathrm{~d}, 16.0)$ & 145.0 & & 154.0 & $5.07(\mathrm{~d}, 3.6)$ & 83.3 & $4.95(\mathrm{~d}, 7.8)$ & 76.6 & $4.90(\mathrm{~d}, 7.8)$ & 76.5 \\
\hline 8 & $6.47(\mathrm{~d}, 16.0)$ & 114.4 & & 126.4 & $3.70(\mathrm{dd}, 9.2,3.8)$ & 53.0 & $4.20(\mathrm{~m})$ & 78.4 & $4.16(\mathrm{~m})$ & 78.5 \\
\hline 9 & & 166.7 & & 144.2 & & 177.7 & $\begin{array}{c}3.55(\mathrm{~d}, 11.6) \\
3.35^{\mathrm{a}}\end{array}$ & 60.6 & $\begin{array}{c}3.53(\mathrm{~d}, 10.2) \\
3.35(\mathrm{dd}, 12.0,4.2)\end{array}$ & 60.6 \\
\hline 10 & & & & 103.8 & & & & & & \\
\hline $1^{\prime}$ & & 173.3 & & 122.3 & & 131.0 & & 128.2 & & 130.5 \\
\hline $2^{\prime}$ & $2.33(t, 7.4)$ & 33.1 & $8.14(\mathrm{~d}, 8.8)$ & 130.2 & $6.99(\mathrm{~d}, 1.2)$ & 111.1 & $7.30(\mathrm{~d}, 2.0)$ & 116.9 & $7.05(\mathrm{~d}, 2.0)$ & 115.9 \\
\hline $3^{\prime}$ & $1.58(\mathrm{~m})$ & 24.1 & $6.94(\mathrm{~d}, 8.8)$ & 115.9 & & 148.2 & & 144.3 & & 144.4 \\
\hline $4^{\prime}$ & $1.37(\mathrm{~m})$ & 25.0 & & 159.8 & & 145.7 & & 146.1 & & 143.8 \\
\hline $5^{\prime}$ & $1.64(\mathrm{~m})$ & 27.9 & $6.94(\mathrm{~d}, 8.8)$ & 115.9 & $6.81^{\mathrm{a}}$ & 115.9 & $6.94(\mathrm{~d}, 8.0)$ & 117.6 & $6.87(\mathrm{~d}, 8.0)$ & 117.3 \\
\hline $6^{\prime}$ & $4.12(t, 6.6)$ & 63.5 & $8.14(\mathrm{~d}, 8.8)$ & 130.2 & $6.85(\mathrm{dd}, 8.2,1.8)$ & 119.5 & $7.21(\mathrm{dd}, 8.0,2.0)$ & 122.1 & $7.00(\mathrm{dd}, 8.0,1.8)$ & 121.6 \\
\hline $7^{\prime}$ & & & & & $5.39(\mathrm{~d}, 3.6)$ & 85.4 & $7.52(\mathrm{~d}, 16.0)$ & 143.9 & $7.12(\mathrm{~d}, 15.8)$ & 136.6 \\
\hline $8^{\prime}$ & & & & & $3.28(\mathrm{~m})$ & 49.3 & $6.38(\mathrm{~d}, 16.0)$ & 117.7 & $6.29(\mathrm{~d}, 15.8)$ & 127.6 \\
\hline $9^{\prime}$ & & & & & $\begin{array}{l}4.14(\mathrm{dd}, 9.2,7.2) \\
3.95(\mathrm{dd}, 9.2,4.0)\end{array}$ & 72.5 & & 168.3 & & 171.2 \\
\hline $3-\mathrm{OCH}_{3}$ & $3.83(\mathrm{~s})$ & 55.7 & & & & & $3.78(\mathrm{~s})$ & 56.1 & $3.76(\mathrm{~s})$ & 56.2 \\
\hline $5-\mathrm{OCH}_{3}$ & & & $3.91(\mathrm{~s})$ & 56.8 & & & & & & \\
\hline $1^{\prime}-\mathrm{OCH}_{3}$ & $3.59(\mathrm{~s})$ & 51.2 & & & & & & & & \\
\hline $3^{\prime}-\mathrm{OCH}_{3}$ & & & & & $3.79(\mathrm{~s})$ & 56.2 & & & & \\
\hline
\end{tabular}


<smiles>COC(=O)CCCCCOC(=O)/C=C/c1ccc(O)c(OC)c1</smiles><smiles>[R]c1cc(-c2oc3c([R])c([R])cc(O)c3c(=O)c2[R])ccc1O</smiles>

4. $\mathrm{R}_{1}=\mathrm{R}_{2}=\mathrm{OH}, \mathrm{R}_{3}=\mathrm{R}_{4}=\mathrm{H}$ 5. $\mathrm{R}_{1}=\mathrm{H}, \mathrm{R}_{2}=\mathrm{OH}, \mathrm{R}_{3}=\mathrm{H}, \mathrm{R}_{4}=\mathrm{OH}$ 6. $\mathrm{R}_{1}=\mathrm{OH}, \mathrm{R}_{2}=\mathrm{Rha}, \mathrm{R}_{3}=\mathrm{R}_{4}=\mathrm{H}$ $7 . \mathrm{R}_{1}=\mathrm{OH}, \mathrm{R}_{2}=\mathrm{Rha}, \mathrm{R}_{3}=\mathrm{OH}, \mathrm{R}_{4}=\mathrm{H}$ 8. $\mathrm{R}_{1}=\mathrm{OH}, \mathrm{R}_{2}=\mathrm{Rha}^{3}-\mathrm{Glc} \mathrm{R}_{3}=\mathrm{OH}, \mathrm{R}_{4}=\mathrm{H}$ 9. $\mathrm{R}_{1}=\mathrm{Rha}^{3}-\mathrm{Glc}, \mathrm{R}_{2}=\mathrm{OH}, \mathrm{R}_{3}=\mathrm{H}, \mathrm{R}_{4}=\mathrm{H}$ 10. $\mathrm{R}_{1}=\mathrm{OH}, \mathrm{R}_{2}=\mathrm{Rha}^{3}-\mathrm{Glc}, \mathrm{R}_{3}=\mathrm{R}_{4}=\mathrm{H}$<smiles>COc1cc([C@H]2Oc3cc(/C=C/C(=O)O)ccc3O[C@@H]2CO)ccc1O</smiles><smiles>COc1cc([C@H]2c3cc(O)c(OC)cc3C[C@@H](CO)[C@H]2CO)ccc1O</smiles><smiles>COc1cc([C@H]2Oc3c(OC)cc(CCCO)cc3[C@@H]2C)ccc1O</smiles><smiles>COC(=O)c1cc(O)c(O)c(O)c1</smiles>

16<smiles>O=C(OCCc1ccc(O)cc1)c1cc(O)c(O)c([18F])c1</smiles>

Figure 1. Chemical structures of compounds 1-17.

Compound 2 showed an $[\mathrm{M}+\mathrm{H}]^{+}$ion peak at $m / z 317.0667$ (calcd. for $\mathrm{C}_{16} \mathrm{H}_{13} \mathrm{O}_{7}, 317.0661$ ) in the HRESIMS spectrum, consistent with the molecular formula of $\mathrm{C}_{16} \mathrm{H}_{12} \mathrm{O}_{7}$. The IR spectrum displayed $\mathrm{OH}\left(3418\right.$ and $\left.3309 \mathrm{~cm}^{-1}\right), \mathrm{C}=\mathrm{C}\left(1662 \mathrm{~cm}^{-1}\right)$ and $\mathrm{MeO}\left(1252 \mathrm{~cm}^{-1}\right)$ bands. The ${ }^{1} \mathrm{H}-\mathrm{NMR}$ spectrum revealed the existence of four active hydrogen protons at $\delta_{\mathrm{H}} 12.01,10.11,9.40$ and 8.75, and a pair of double peaks $\left(\delta_{\mathrm{H}} 8.14(2 \mathrm{H}, \mathrm{d}, J=8.8 \mathrm{~Hz})\right.$ and $\left.6.94(2 \mathrm{H}, \mathrm{d}, J=8.8 \mathrm{~Hz})\right)$ ascribed to a 1,4-disubstituted benzene ring, as well as one single peak at $\delta_{\mathrm{H}} 6.56$. The ${ }^{13} \mathrm{C}-\mathrm{NMR}$ spectrum revealed the presence of 16 $\mathrm{C}$-atoms, including 15 aromatic carbons at $\delta_{\mathrm{C}} 176.9,159.8,154.0,152.7,147.6,144.2,135.9,130.2,130.2$, $126.4,122.3,115.9,115.9,103.8$ and 95.4, and a $\mathrm{MeO}$ at $\delta_{\mathrm{C}}$ 56.8. Comparison the NMR data (Table 1) of compound 2 with those of herbacetin [16] revealed that the NMR data of compound 2 were similar to those of herbacetin, except for an extra $\mathrm{MeO}$ group. Based on the above NMR data, a MeO group substituting the $\mathrm{OH}$ at $\mathrm{C}-7$ was proposed. This was further supported by HMBC correlation (Figure 2) between $\delta_{\mathrm{H}} 3.91\left(\mathrm{OCH}_{3}\right)$ and $\delta_{\mathrm{C}} 154.0(\mathrm{C}-7)$. When comparing its ${ }^{13} \mathrm{C}-\mathrm{NMR}$ data to the previously published data of herbacetin 7-methyl ether [17], wrong assignments of C-5 ( $\left.\delta_{\mathrm{C}} 153.72\right), \mathrm{C}-7\left(\delta_{\mathrm{C}} 159.39\right)$ and C-9 $\left(\delta_{\mathrm{C}} 152.40\right)$ were noted in those published results. Consequently, compound 2 was identified as herbacetin 7-methyl ether, and its ${ }^{13} \mathrm{C}$-NMR data were corrected (see Table 1). 

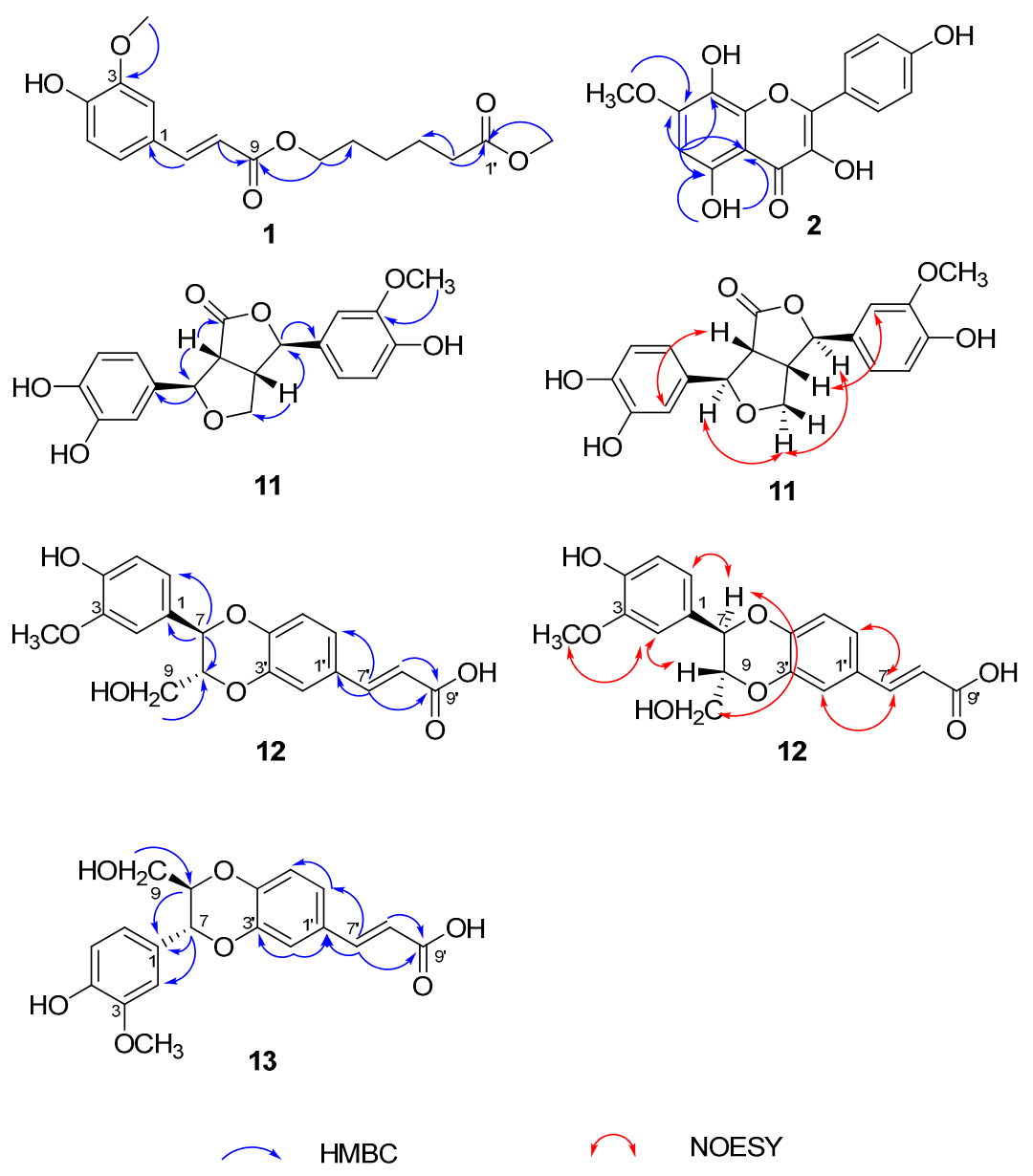

Figure 2. Key HMBC or NOESY correlations of compounds 1, 2 and 11-13.

The molecular formula of compound $\mathbf{1 1}$ was determined as $\mathrm{C}_{19} \mathrm{H}_{18} \mathrm{O}_{7}$ by its HRESIMS [M $\left.+\mathrm{Na}\right]^{+}$ signal at $\mathrm{m} / z 381.0953$ (calcd. for $\mathrm{C}_{19} \mathrm{H}_{18} \mathrm{O}_{7} \mathrm{Na}, 381.0950$ ). The IR absorptions suggested the existence of $\mathrm{OH}\left(3402 \mathrm{~cm}^{-1}\right), \mathrm{C}=\mathrm{O}\left(1755 \mathrm{~cm}^{-1}\right)$ and $\mathrm{C}=\mathrm{C}\left(1650 \mathrm{~cm}^{-1}\right)$ functionalities. The chemical shifts from $\delta_{\mathrm{H}} 6.99$ to 6.64 were in the aromatic region in the ${ }^{1} \mathrm{H}-\mathrm{NMR}$ spectrum, which indicated the existence of two 1,3,4-trisubstituted benzene systems $\left(\delta_{\mathrm{H}} 6.79(1 \mathrm{H}, \mathrm{d}, J=1.2 \mathrm{~Hz}), 6.74(1 \mathrm{H}\right.$, overlapped $)$ and $6.64(1 \mathrm{H}$, $\mathrm{dd}, J=8.2,1.8 \mathrm{~Hz})$, and $6.99(1 \mathrm{H}, \mathrm{d}, J=1.2 \mathrm{~Hz}), 6.85(1 \mathrm{H}, \mathrm{dd}, J=8.2,1.8 \mathrm{~Hz})$ and $6.81(1 \mathrm{H}$, overlapped)), furthermore, a pair of oxymethylene signals $\left(\delta_{\mathrm{H}} 4.14(1 \mathrm{H}, \mathrm{dd}, J=9.2,7.2 \mathrm{~Hz})\right.$ and 3.95 $(1 \mathrm{H}, \mathrm{dd}, J=9.2,4.0 \mathrm{~Hz})$ ), two oxymethine signals $\left(\delta_{\mathrm{H}} 5.39(1 \mathrm{H}, \mathrm{d}, J=3.6 \mathrm{~Hz})\right.$ and $\left.5.07(1 \mathrm{H}, \mathrm{d}, J=3.6 \mathrm{~Hz})\right)$ were also visible in the ${ }^{1} \mathrm{H}-\mathrm{NMR}$ spectrum. The ${ }^{13} \mathrm{C}$-NMR spectrum displayed $19 \mathrm{C}$-atom signals, including two benzene rings ( $\delta \mathrm{c} 147.4,145.4,131.8,117.3,115.8$ and 114.0$)$ and $\left(\delta_{\mathrm{C}} 148.2,145.7,131.0\right.$, $119.5,115.9$ and 111.0$)$, a methylene $\left(\delta_{\mathrm{C}} 72.5\right)$, four methines $\left(\delta_{\mathrm{C}} 85.4,83.3,53.0\right.$ and 49.3$)$ and an ester carbonyl carbon $\left(\delta_{\mathrm{C}}\right.$ 177.7). The NMR data of $\mathbf{1 1}$ (Table 1) were closely similar to those of 4-ketopinoresinol [18], the chemical structure with the loss of $\mathrm{MeO}$ at $\mathrm{C}-3$ was deduced on the basis of these data. This was further confirmed by the key HMBC correlation (Figure 2) from $\delta_{\mathrm{H}} 3.79\left(\mathrm{OCH}_{3}\right)$ to $\delta_{\mathrm{C}} 148.2\left(\mathrm{C}-3^{\prime}\right)$. The relative configuration was established by NOESY correlations (Figure 2) between

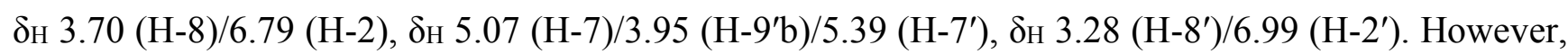
compound 11 gave a positive specific rotation $[\alpha]_{\mathrm{D}}^{25}+4.97(c 0.2, \mathrm{MeOH})$, opposite that of $(-)-3,4,3^{\prime}, 4^{\prime}-$ tetrahydroxy-9,7' $\beta$-epoxylignano-7 $\beta, 9^{\prime}$-lactone $\left([\alpha]_{\mathrm{D}}^{25}-5.8(c 0.1, \mathrm{MeOH})\right)$ [19]. Thus, compound 11 was identified as $\left(7 \beta, 7^{\prime} \beta, 8 \alpha, 8^{\prime} \alpha\right)$-3'-methoxy-9-oxo-7,9',7,9'-diepoxylignan-3,4,4'-triol. 
Compound 12 was isolated as a white amorphous powder, the HRESIMS of compound 12 showed an $[\mathrm{M}+\mathrm{Na}]^{+}$ion peak at $m / z 381.0950$ (calcd. for $\mathrm{C}_{19} \mathrm{H}_{18} \mathrm{O}_{7} \mathrm{Na}$ : 381.0950 ) for the molecular formula $\mathrm{C}_{19} \mathrm{H}_{18} \mathrm{O}_{7}$. The IR spectrum showed $3438 \mathrm{~cm}^{-1}(\mathrm{OH})$ and $1688 \mathrm{~cm}^{-1}(\mathrm{C}=\mathrm{O})$ groups. The ${ }^{1} \mathrm{H}-\mathrm{NMR}$ spectrum of compound 12 displayed two pairs of $\mathrm{ABX}$ proton signals: $\delta \mathrm{H} 7.30(1 \mathrm{H}, \mathrm{d}, J=2.0 \mathrm{~Hz}), 7.21$ $(1 \mathrm{H}, \mathrm{dd}, J=8.0,2.0 \mathrm{~Hz})$ and $6.94(1 \mathrm{H}, \mathrm{d}, J=8.0 \mathrm{~Hz})$, as well as $\delta_{\mathrm{H}} 7.01(1 \mathrm{H}, \mathrm{d}, J=1.8 \mathrm{~Hz}), 6.85(1 \mathrm{H}$, $\mathrm{d}, J=8.0,1.8 \mathrm{~Hz})$ and $6.80(1 \mathrm{H}, \mathrm{d}, J=8.0 \mathrm{~Hz})$. A pair of proton signals $\left(\delta_{\mathrm{H}} 7.52(1 \mathrm{H}, \mathrm{d}, J=16.0 \mathrm{~Hz})\right.$ and $6.38(1 \mathrm{H}, \mathrm{d}, J=16.0 \mathrm{~Hz})$ of trans-double bonds were also seen in the ${ }^{1} \mathrm{H}-\mathrm{NMR}$ spectrum. Accordingly, the ${ }^{13} \mathrm{C}$-NMR and DEPT-135 spectra gave $19 \mathrm{C}$-atom signals. Except for a MeO group at $\delta_{\mathrm{C}} 56.1$, there remained 18 carbons, and a 3,4-disubstituted cinnamic acid $\left(\delta_{\mathrm{C}} 168.3,146.1,144.3,143.9,128.2,122.1\right.$, $117.7,117.6$ and 116.9) linked with a 7,8-disubstituted 3-methoxy-4-hydroxy-phenylpropanol $\left(\delta_{\mathrm{C}} 148.1\right.$, 147.6, 127.7, 121.0, 115.8, 112.2, 78.4, 76.6 and 60.6) through a C-8-O-C-3' and C-7-O-C-4' linkage pattern was deduced. By comparison with the NMR data (Table 1) of compound 12 with those of arteminorin D [20], the data were seen to be the same as those of this compound. In the previous report, the absolute configuration of arteminorin D was not determined, so, the absolute configuration of compound 12 was elucidated by 2D NMR and CD exciton chirality methods in our work. The relative configuration (Figure 2) of compound 12 was identified by NOESY spectrum and the same as the literature reported (He et al., 2009). The UV spectrum (Figure 3) of compound 12 showed an absorption at $222 \mathrm{~nm}$ attributable to the benzene moiety $\left(\pi \rightarrow \pi^{*}\right)$. Corresponding to this UV absorption, the CD spectrum of compound 12 showed a negative Cotton effect at $222 \mathrm{~nm}$ due to the transition interaction between two different benzene moieties in the structure. The above information demonstrated a negative chirality for compound $\mathbf{1 2}$, and the two aforementioned chromophores should be oriented counterclockwise in space (Figure 3). Thus, compound 12 was elucidated as $(7 R, 8 R)-3$-methoxy-8'-carboxy-7'-en-3',8epoxy-7,4'-oxyneolignan-4,9-diol.

The HRESIMS of compound $\mathbf{1 3}$ showed an $[\mathrm{M}+\mathrm{Na}]^{+}$ion peak at $\mathrm{m} / z 381.0952[\mathrm{M}+\mathrm{Na}]^{+}$(calcd. for $\left.\mathrm{C}_{19} \mathrm{H}_{18} \mathrm{O}_{7} \mathrm{Na}: 381.0950\right)$ for the same molecular formula $\left(\mathrm{C}_{19} \mathrm{H}_{18} \mathrm{O}_{7}\right)$ as that of compound 12. Comparison the NMR data (Table 1) of compound 13 with those of compound 12 revealed that the NMR data of compound $\mathbf{1 3}$ were similar. A 3,4-disubstituted cinnamic acid linked with a 7,8-disubstituted 3-methoxy-4-hydroxy-phenylpropanol with different linkage patterns from that of compound 12 was deduced. Although no HMBC correlations from H-7 to C-3' or H-8 to C-4' were observed, the diagnostic chemical shifts of C-7 ( $\left.\delta_{\mathrm{C}} 76.5\right), \mathrm{C}-8\left(\delta_{\mathrm{C}} 78.5\right), \mathrm{C}-3^{\prime}\left(\delta_{\mathrm{C}} 144.4\right)$ and $\mathrm{C}-4^{\prime}\left(\delta_{\mathrm{C}} 143.8\right)$, combined with the established molecular formula, $\mathrm{C}_{19} \mathrm{H}_{18} \mathrm{O}_{7}$, suggested a linkage pattern of C-7-O-C-3' and C-8-O-C-4'. Furthermore, a large coupling constant between $\mathrm{H}-7$ and $\mathrm{H}-8(\mathrm{~J}=7.8 \mathrm{~Hz})$ indicated a trans relationship of the two protons. This chemical structure (Figure 1) was reported in a Chinese patent [21] without the absolute configuration, so the absolute configuration of compound $\mathbf{1 3}$ was also elucidated using the CD exciton chirality method (Figure 3), and the absolute configuration of compound $\mathbf{1 3}$ was determined as $(7 R, 8 R)$. Thus, compound 13 was elucidated as $(7 R, 8 R)-3$-methoxy-8'-carboxy-7'-en-3',7-epoxy-8, $4^{\prime}$ oxyneolignan-4,9-diol.

In addition, the other 12 known phenolic compounds were identified as 5,7,3',5'-tetrahydroxydihydroflavone (3) [22], kaempferol (4) [23], luteolin (5) [24], kaempferol-7-O- $\alpha$-L-rhamnoside (6) [23], rhodionin (7) [6], rhodiosin (8) [6], ternatumoside II (9) [25], crenuloside (10) [6], (+)-isolarisiresinol (14) [26], (+)-dihydrodehydrodiconiferyl alcohol (15) [27], methyl gallate (16) [28] and 2-(4-hydroxyphenyl) ethyl 3,4,5-trihydroxybenzoate (17) [29] by comparing their physical and spectral data with literature values. 


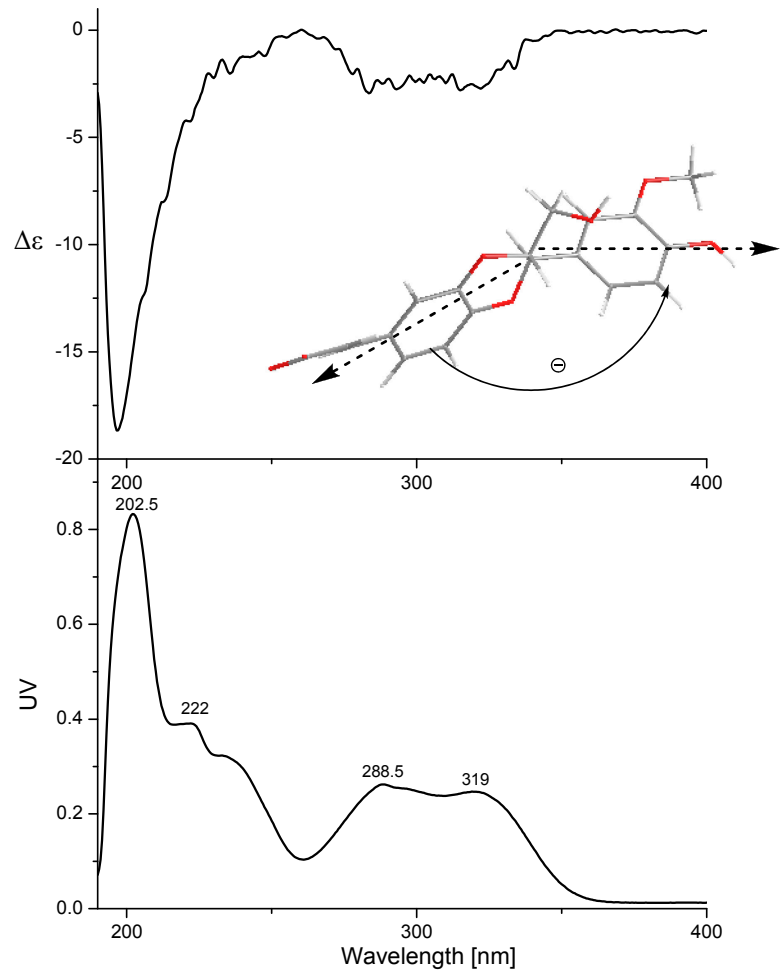

(A)

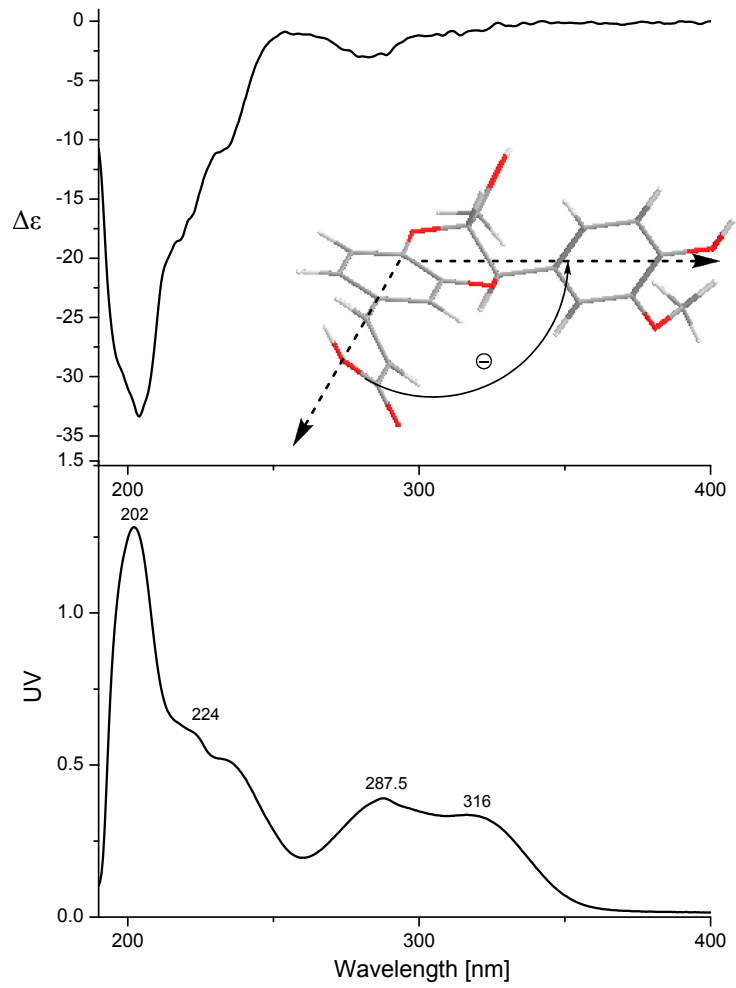

(B)

Figure 3. CD and UV spectra of compounds $12(\mathrm{~A})$ and $13(\mathbf{B})$, where the arrow denotes the electronic transition dipole of the chromophores. (-) means the two chromophores should be oriented counterclockwise in space; $(+)$ means the two chromophores should be oriented clockwise in space. 


\subsection{Antioxidant Activities}

The DPPH and ABTS radical-scavenging assays are effective methods used to evaluate the antioxidant activity of natural products. As shown in Table 2, new compound 1 exhibited no radical-scavenging activity, while compounds $\mathbf{2 - 1 0}$ showed potent radical-scavenging activities comparable to ascorbic acid, compounds 16 and 17 exhibited more intense radical-scavenging activities. In all, the radical-scavenging activity of compounds is also attributed to the hydroxyl groups substituted on the aromatic ring.

Table 2. The $\mathrm{IC}_{50}$ values in $\mu \mathrm{M}$ of antioxidant activities of $\mathbf{1}-\mathbf{1 7}(n=3)$.

\begin{tabular}{ccc}
\hline Compounds & DPPH IC $_{\mathbf{5 0}}(\boldsymbol{\mu M})^{\mathbf{a}}$ & ${\text { ABTS } \mathbf{I C}_{\mathbf{5 0}}(\boldsymbol{\mu M})^{\mathbf{a}}}^{\mathbf{1}}$ \\
$\mathbf{1}$ & $>500^{\mathrm{b}}$ & $>500$ \\
$\mathbf{2}$ & $114.3 \pm 4.4$ & $87.0 \pm 7.9$ \\
$\mathbf{3}$ & $73.8 \pm 2.9$ & $129.8 \pm 12.3$ \\
$\mathbf{5}$ & $91.6 \pm 1.4$ & $125.4 \pm 9.8$ \\
$\mathbf{6}$ & $94.3 \pm 2.3$ & $123.9 \pm 10.4$ \\
$\mathbf{7}$ & $83.0 \pm 3.5$ & $123.7 \pm 12.8$ \\
$\mathbf{8}$ & $104.7 \pm 1.8$ & $63.7 \pm 8.5$ \\
$\mathbf{9}$ & $96.5 \pm 2.3$ & $53.1 \pm 4.8$ \\
$\mathbf{1 0}$ & $260.5 \pm 36.4$ & $320.2 \pm 22.6$ \\
$\mathbf{1 1}$ & $>5.1 \pm 3.3$ & $110.8 \pm 10.7$ \\
$\mathbf{1 2}$ & $>500$ & $>500$ \\
$\mathbf{1 3}$ & $>500$ & $>500$ \\
$\mathbf{1 4}$ & $227.1 \pm 33.9$ & $>500$ \\
$\mathbf{1 5}$ & $>500$ & $>500$ \\
$\mathbf{1 6}$ & $52.8 \pm 3.3$ & $50.0 \pm 4.9$ \\
$\mathbf{1 7}$ & $79.5 \pm 1.7$ & $65.0 \pm 3.9$ \\
Ascorbic acid & $88.6 \pm 1.9$ & $89.8 \pm 6.8$ \\
\hline represented as mean $\pm \mathrm{SD}^{\mathrm{b}}{ }^{\mathrm{T}}$ The $\mathrm{IC}_{50}$ value of sample is higher than $500 \mu \mathrm{M}$.
\end{tabular}

\subsection{Compounds Treatment Stimulates IFN- $\gamma$ Production Activities}

As reported in the literature [30,31], nitric oxide production by activated macrophages in vitro and in vivo is dependent on IFN- $\gamma$, which is corresponding to the immunomodulatory effect [32]. To further evaluate the biological of these isolated phenolic compounds, the inducibility to IFN- $\gamma$ release was measured in cell culture supernatants. As shown in Figure 4, compounds 1, 8, 9, 12, 13, 14 and 15 could moderately stimulate IFN- $\gamma$ expression. Finally, CCK- 8 assays were used to determine if these isolates suppress the production of IFN- $\gamma$. As Figure 5 shows, there was no significant reduction in cell viability by these compounds (100 $\mu \mathrm{M}$ concentration). Therefore, we can conclude that the four lignans (compounds 12, 13, 14 and 15) and the two flavonoid glycosides (compounds 8 and 9) from $R$. crenulata have the ability of inducing IFN- $\gamma$ production, moreover, the new compound $\mathbf{1}$ also possesses the inducing IFN- $\gamma$ release activity. These compounds would be the active chemical constituents related to the immunomodulatory effect of $R$. crenulata. 


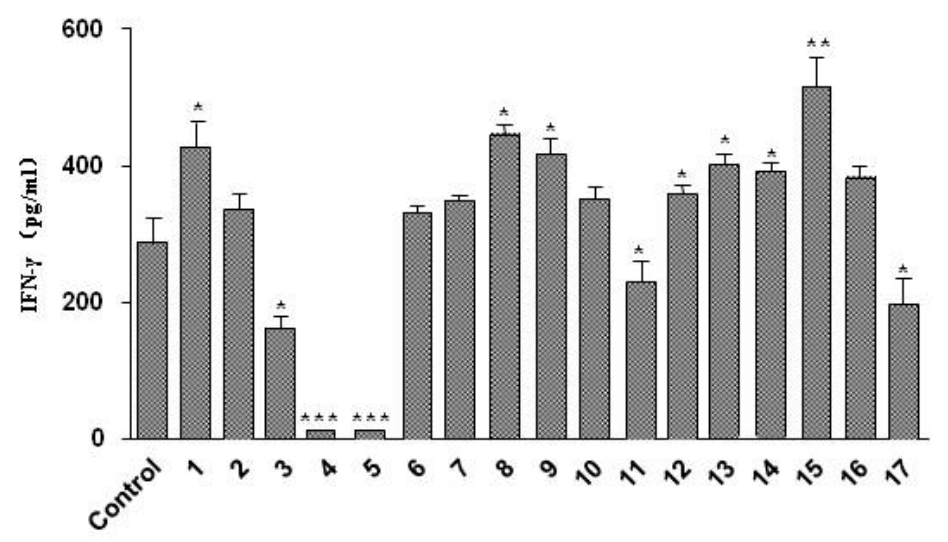

Figure 4. IFN- $\gamma$ production by spleen lymphocyte cells treated with compounds 1-17. Valus are means \pm S.E.M., $n=3 ; * p<0.05 ; * * p<0.01 ; * * * p<0.005$.

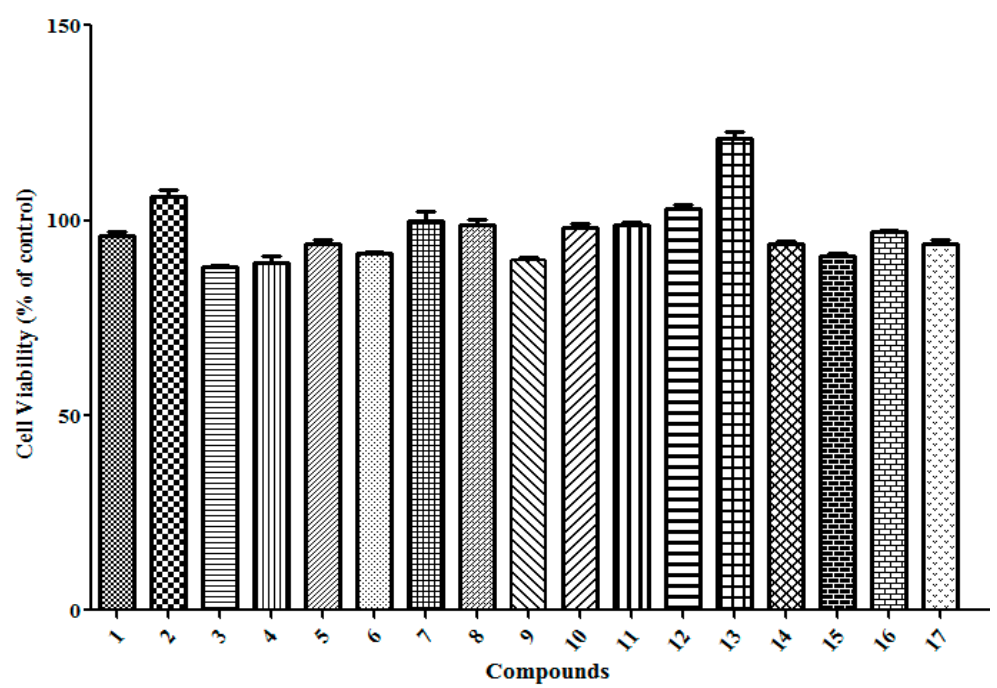

Figure 5. Cell viability of mouse spleen lymphocyte cells after 48 h treatment by $100 \mu \mathrm{M}$ concentration of compounds 1-17 using CCK-8 assay (data points represent the mean \pm S.D., $n=3)$.

\section{Experimental Section}

\subsection{General Procedures}

All reagents were of HPLC or analytical grade and were purchased from Tianjin Concord Chemical Company (Tianjin, China). Optical rotation values were measured by a P-1020 polarimeter (JASCO International Co., Ltd., Tokyo, Japan). IR spectra were measured on a Perkin Elmer spectrum 65 FT-IR spectrometer (PerkinElmer, Waltham, MA, USA). HRESIMS data were determined by an Agilent 6210 ESI/TOF mass spectrometer (Agilent Co., Santa Clara, CA, USA), the full scan mass spectra data were acquired in positive and negative ion modes. Acquisition parameters are as follows: capillary voltage was $3000 \mathrm{~V}$ for ESI $(+)$ and $2600 \mathrm{~V}$ for ESI (-); cone voltage was $45 \mathrm{~V}$; the ESI source temperature was $100{ }^{\circ} \mathrm{C}$; the desolvation temperature was $350{ }^{\circ} \mathrm{C}$; the nitrogen $\left(\mathrm{N}_{2}\right)$ was used as desolvation gas at flow rates of $600 \mathrm{~L} / \mathrm{h}$ for both ESI (+) and ESI (-); and the range of full scan was set at $\mathrm{m} / \mathrm{z} 150-1000 \mathrm{Da}$.). NMR spectra were recorded on a Bruker-AVIII-400/600M spectrometer (Bruker Co., Geneva, 
Switzerland). CD spectra were recorded on a JASCO J-720W spectropolarimeter (JASCO). The ODs were recorded on a Flexstation 3 (Molecular Devices Co., Sunnyvale, CA, USA). Preparative HPLC: Agilent 1260 system equipped with a preparative Cosmosil $\mathrm{C}_{18}(5 \mu \mathrm{m}, 20 \mathrm{~mm} \times 250 \mathrm{~mm})$ column (Agilent Co.). Column chromatography (CC): silica gel ( $\mathrm{SiO}_{2} ; 200-300 / 400-500$ mesh, Qingdao Marine Chemical Factory, Qingdao, China); Sephadex LH-20: (GE Healthcare UK Ltd, Buckinghamshire, UK); D101 macroporous adsorption resin (Tianjin Haiguang Chemical Company, Tianjin, China); ODS (ODS-A-HG 5-50 $\mu \mathrm{m}$, YMC Co., Kyoto, Japan) TLC: silica gel GF254 ( $\mathrm{SiO}_{2}$; 400-500 mesh, Qingdao Marine Chemical Factory, Qingdao, China). 2,2-di-phenyl-1-picrylhydrazyl (DPPH) (Sigma Corporation, Ronkonkoma, New York, NY, USA). 2,2'-azino-bis(3-ethylbenzothiazoline-6-sulfonic acid) (ABTS) (Shanghai Sangon Biological Coporation, Shanghai, China). $\mathrm{K}_{2} \mathrm{~S}_{2} \mathrm{O}_{8}$ (Tianjin Guangfukeji Development Corporation, Tianjin, China).

\subsection{Plant Materials}

The roots of Rhodiola crenulata (HK. f. et.Thoms) H. Ohba were obtained from Shijiazhuang Yiling Pharmaceutical Co., Ltd. (Shijiazhuang, China), and were identified by Dr. Chun-Hua Wang of Tianjin University of Traditional Chinese Medicine. A voucher specimen (No. 20121011CH) was deposited in Tianjin Key Laboratory of Modern Chinese Medicine, Taida, Tianjin, China.

\subsection{Extraction and Isolation}

The roots of $R$. crenulata $(25.0 \mathrm{~kg})$ were extracted three times with $95 \% \mathrm{EtOH}(50 \mathrm{~L})$ with heating for $2 \mathrm{~h}$. The solvent was concentrated to give a crude extract ( $2500 \mathrm{~g})$, which was subjected to column chromatography (CC) (D101 macroporous adsorption resin, EtOH 95\%, 50\% and 30\%). Then 95\% EtOH extract $(400 \mathrm{~g})$ was subjected to silica gel $\mathrm{CC}(120 \mathrm{~cm} \times 15 \mathrm{~cm})$ eluted with a gradient of $\mathrm{CH}_{2} \mathrm{Cl}_{2} / \mathrm{MeOH}$ (100:0-100:20) to afford eight fractions (F1-F8). F1 (5 g) was further separated by silica gel CC with petroleum ether/ethyl acetate (100:0-100:40) to afford eight subfractions F1-1 to F1-8. Subfraction F1-7 (270 mg) was purified by preparative HPLC with $\mathrm{MeOH} / \mathrm{H}_{2} \mathrm{O}$ (72:28) to afford compound 1 (42 mg). F2 (42 g) was subjected to silica gel column chromatography eluting with $\mathrm{CH}_{2} \mathrm{Cl}_{2} / \mathrm{MeOH}$ (100:0-100:10) to afford 42 subfractions. Compound 4 (330 mg) was obtained from F2-2 and compound $5(120 \mathrm{mg})$ from F2-10, respectively. Subfractions F2-12 to F2-20 were merged and purified by preparative $\mathrm{HPLC}$ with $\mathrm{MeOH} / \mathrm{H}_{2} \mathrm{O}(58: 42)$ to afford compounds 14 (25 mg) and $\mathbf{1 5}(33 \mathrm{mg})$. Subfraction F2-22 (310 mg) was subjected to Sephadex $\mathrm{LH}-20$ column chromatography with $\mathrm{CH}_{2} \mathrm{Cl}_{2} / \mathrm{MeOH}(50: 50)$ and preparative $\mathrm{HPLC}$ with $\mathrm{MeOH} / \mathrm{H}_{2} \mathrm{O}(55: 45)$ to afford compound 12 (44 mg). Subfractions F2-23 to F2-30 were merged and subjected to Sephadex LH-20 column chromatography with $\mathrm{CH}_{2} \mathrm{Cl}_{2} / \mathrm{MeOH}$ (50:50) and preparative HPLC with $\mathrm{MeOH} / \mathrm{H}_{2} \mathrm{O}$ (48:52) to afford compound 13 (24 mg). F2-35 to F2-42 were merged and separated by preparative $\mathrm{HPLC}$ with $\mathrm{MeOH} / \mathrm{H}_{2} \mathrm{O}$ (44:56) to afford compound 11 (37 mg). F3 (36 g) was separated by silica gel $\mathrm{CC}$ with $\mathrm{CH}_{2} \mathrm{Cl}_{2} / \mathrm{MeOH}$ (100:0-100:20) to afford 34 subfractions. Compound 3 (47 mg) was obtained from F3-1 using a Sephadex $\mathrm{LH}-20$ column with $\mathrm{CH}_{2} \mathrm{Cl}_{2} / \mathrm{MeOH}$ (50:50). F3-8 (85 mg) was washed with methanol to obtain feathery crystals of compound 16 (33 $\mathrm{mg}$ ). Fractions F3-6 to F3-13 were merged and subjected to Sephadex LH-20 column chromatography with $\mathrm{CH}_{2} \mathrm{Cl}_{2} / \mathrm{MeOH}$ (50:50) to obtain compound 2 (58 mg) and a mixture of compounds 2 and 17 (89 mg), which were purified by preparative $\mathrm{HPLC}$ with $\mathrm{MeOH} / \mathrm{H}_{2} \mathrm{O}(55: 45)$ to yield compound 17 (22 $\mathrm{mg}$ ). 
F4 (26 g) was separated by ODS CC with $\mathrm{MeOH} / \mathrm{H}_{2} \mathrm{O}(20: 80,40: 60,60: 40$ and 80:20) to afford 10 subfractions. Compound 6 (105 mg) was obtained with a needle crystals from F4-1. F4-4 (3.7 g) was subjected to Sephadex $\mathrm{LH}-20 \mathrm{CC}$ with $\mathrm{CH}_{2} \mathrm{Cl}_{2} / \mathrm{MeOH}$ (50:50) to give compound 7 (69 mg). F5 (26 g) was subjected to ODS CC with $\mathrm{MeOH} / \mathrm{H}_{2} \mathrm{O}(20: 80,40: 60,60: 40,80: 20)$ to get 11 subfractions. F5-2 (1.4 g) was separated by Sephadex LH-20 CC with MeOH to afford compound 9 (52 mg) and preparative HPLC with $\mathrm{MeOH} / \mathrm{H}_{2} \mathrm{O}$ (33:67) to afford compound 10 (24 mg). F5-4 (1.1 g) was separated by Sephadex $\mathrm{LH}-20 \mathrm{CC}$ with $\mathrm{MeOH}$ to obtain needle crystals to give compound 8 (420 mg).

\subsection{Compound Characterization}

Rhodiolate (1): Light yellow solid; IR (KBr) vmax: 3411, 2925, 2854, 1734, 1708, 1633, 1592, 1514, $1208 \mathrm{~cm}^{-1}$; UV (MeOH) $\lambda_{\max }: 324,197.5 \mathrm{~nm}$; HRESIMS m/z $321.1338[\mathrm{M}-\mathrm{H}]^{-}$(calcd for $\mathrm{C}_{17} \mathrm{H}_{21} \mathrm{O}_{6}$ : 321.1338), ${ }^{1} \mathrm{H}-(400 \mathrm{MHz})$ and ${ }^{13} \mathrm{C}-\mathrm{NMR}(100 \mathrm{MHz})$ data, see Table 1.

Herbacetin 7-methyl ether (2): Yellow needles; IR (KBr) vmax: 3418, 3309, 2922, 1662, $1252 \mathrm{~cm}^{-1}$; UV (MeOH) $\lambda_{\max }$ : 199.5, 274.5, 331, $380 \mathrm{~nm}$; HRESIMS m/z $317.0667[\mathrm{M}+\mathrm{H}]^{+}$(calcd for $\mathrm{C}_{16} \mathrm{H}_{13} \mathrm{O}_{7}$ : $317.0661)$, ${ }^{1} \mathrm{H}-(400 \mathrm{MHz})$ and ${ }^{13} \mathrm{C}-\mathrm{NMR}(100 \mathrm{MHz})$ data, see Table 1.

(+)-Syzygiresinol A (11): brown viscous substance; $[\alpha]_{\mathrm{D}}^{25}+4.97\left(c\right.$ 0.2, MeOH); IR (KBr) v $v_{\max }$ : 3402, 3280, 2921, 1755, 1650, $1232 \mathrm{~cm}^{-1}$; UV (MeOH) $\lambda_{\max }: 203,282.5 \mathrm{~nm}$; HRESIMS $\mathrm{m} / z 381.0953$ $[\mathrm{M}+\mathrm{Na}]^{+}$(calcd for $\left.\mathrm{C}_{19} \mathrm{H}_{18} \mathrm{O}_{7} \mathrm{Na}: 381.0950\right),{ }^{1} \mathrm{H}-(400 \mathrm{MHz})$ and ${ }^{13} \mathrm{C}-\mathrm{NMR}$ (100 MHz) data, see Table 1.

(7R,8R)-3-Methoxy-8'-carboxy-7'-en-3',8-epoxy-7,4'-oxyneolignan-4,9-diol (12): White amorphous powder; $[\alpha]_{\mathrm{D}}^{25}-4.67$ (c 0.2, MeOH); IR (KBr) v $v_{\max }$ : 3438, 2978, 1688, 1612, 1505, 1265, 1125, $1048 \mathrm{~cm}^{-1}$; UV (MeOH) $\lambda_{\max }: 202,222,288.5,319 \mathrm{~nm}$; HRESIMS $m / z 381.0950[\mathrm{M}+\mathrm{Na}]^{+}$(calcd for $\mathrm{C}_{19} \mathrm{H}_{18} \mathrm{O}_{7} \mathrm{Na}$ : 381.0950), ${ }^{1} \mathrm{H}-(400 \mathrm{MHz})$ and ${ }^{13} \mathrm{C}-\mathrm{NMR}(100 \mathrm{MHz})$ data, see Table 1.

(7R,8R)-3-Methoxy-8'-carboxy-7'-en-3',7-epoxy-8,4'-oxyneolignan-4,9-diol (13): Yellow viscous powder; $[\alpha]_{\mathrm{D}}^{25}-9.00(c 0.2, \mathrm{MeOH})$; IR (KBr) $v_{\max }: 3427,2956,1537,1242,1098,1024 \mathrm{~cm}^{-1}$; UV (MeOH) $\lambda_{\max }: 202,224,287.5,316 \mathrm{~nm}$; HRESIMS $m / z 381.0952[\mathrm{M}+\mathrm{Na}]^{+}$, calcd for $\mathrm{C}_{19} \mathrm{H}_{18} \mathrm{O}_{7} \mathrm{Na}$ : 381.0950), ${ }^{1} \mathrm{H}-(400 \mathrm{MHz})$ and ${ }^{13} \mathrm{C}-\mathrm{NMR}(100 \mathrm{MHz})$ data, see Table 1.

\subsection{Antioxidant Assay}

The DPPH method was widely used to evaluate the antioxidant activity [33,34]. We divided them into three groups, including sample group, control group and blank group. In a 96-well microplate, $150 \mu \mathrm{L}$ of DPPH solution $(250 \mu \mathrm{M})$ was added to $50 \mu \mathrm{L}$ of the test sample in methanol at different concentrations. The OD values of the reaction mixtures was recorded at $517 \mathrm{~nm}$ using a Flexstation 3 for $30 \mathrm{~min}$ at $30^{\circ} \mathrm{C}$. The DPPH-scavenging activity was calculated by the following formula: \% scavenging activity $=100 \times 1-\left(\mathrm{OD}_{\text {sample }}-\mathrm{OD}_{\text {blank }}\right) / \mathrm{OD}_{\text {control}}, \mathrm{OD}_{\text {sample }}=$ absorbance of sample and $\mathrm{DPPH}$, ODblank $=$ absorbance of sample and methanol, OD $_{\text {control }}=$ absorbance of DPPH and methanol. IC50, the concentration of sample needed to scavenge $50 \%$ of DPPH radical and was obtained by plotting the DPPH-scavenging percentage of each sample against the sample concentration. Ascorbic acid was used as the positive control in this experiment. 
The ABTS assay was adopted to evaluate the antioxidant activity of phenolic compounds as well as the free radical-scavenging assay [35]. This assay was based on the oxidation of radical cation $\mathrm{ABTS}^{+}$, which was read at $734 \mathrm{~nm}$. The working ABTS reagent was prepared by mixing the same volume of ABTS methanol solution ( $7 \mathrm{mM}$ ) and $\mathrm{K}_{2} \mathrm{~S}_{2} \mathrm{O}_{8}$ solution (6.63 $\mathrm{mg}$ to $10 \mathrm{~mL} 50 \%$ methanol). Then diluted with methanol 1:3. The ABTS scavenging activity share the same method. Except that the OD values of the reaction mixtures were recorded at $734 \mathrm{~nm}$ using a Flexstation 3 for $10 \mathrm{~min}$ at $30^{\circ} \mathrm{C}$.

\subsection{Cell Culture and Cytokine Assay}

The spleen lymphocyte cells obtained from Balb-c mouse were maintained in RPMI 1640 medium containing $10 \%$ heat inactivated fetal bovine serum, $1 \%$ penicillin-streptomycin at $37{ }^{\circ} \mathrm{C}$ in a humidified atmosphere containing $5 \% \mathrm{CO}_{2}$ and $95 \%$ air. For compounds treatment tests, cells were cultured in triplicate in Coster flat-bottom cell culture plates (Corning Inc., Corning, NY, USA). Cells were plated at a density of $2 \times 10^{6}$ cells/well in 24-well cell culture plates. Compounds to be tested were initially dissolved in $10 \mu \mathrm{L}$ of DMSO, and then RPMI 1640 was added to make solutions in a series of concentration. The final concentration of test compounds was $10 \mu \mathrm{M}$. Cells were supplemented with the test compounds as stimulation with $1 \mu \mathrm{g} / \mathrm{mL}$ Con A. The activated cells were further incubated for $48 \mathrm{~h}$. Control cells were grown under indentical conditions but were only exposed to Con A.

After an incubation period $(48 \mathrm{~h})$, supernatants of cells were analyzed for IFN- $\gamma$ secretion. Concentrations of IFN- $\gamma$ were determined by ELISA kits (eBioscience, San Diego, CA, USA), following the manufacturer instructions.

\subsection{Cell Viability Test}

Cell viability was determined using a CCK-8 cell proliferation and cytotoxicity assay kit (Beyotime Institute of Biotechnology, Haimen, China), according to the supplier's manual. Dispense $100 \mu \mathrm{L}$ of cell suspension (5000 cells/well) in a 96-well plate. Pre-incubate the plate for $24 \mathrm{~h}$ in a humidified incubator (at $37^{\circ} \mathrm{C}, 5 \% \mathrm{CO}_{2}$ ). Add $10 \mu \mathrm{L}$ of $100 \mu \mathrm{M}$ concentrations of compounds to be tested to the plate for $48 \mathrm{~h}$ in the incubator. Briefly, at the end of the drug treatment period, $10 \mu \mathrm{L} \mathrm{CCK}-8$ solutions were fed to each well of the culture plate (containing $100 \mu \mathrm{L}$ medium). After $4 \mathrm{~h}$ incubation, the optical density of the assay solution was measured at $450 \mathrm{~nm}$ with a spectrophotometer (BioTek, Winooski, Vermont, VT, USA).

\section{Conclusions}

In summary, the functional food, $R$. crenulata (HK. f. et.Thoms) H. Ohba, with its unique medicinal effects, has attracted increasing attention in the food and pharmaceutical fields. In our work, isolation and characterization resulted in two new and 15 known phenolic compounds, which structures were elucidated by chemical and spectroscopic analyses, and the absolute configurations of two lignan isomers were confirmed for the first time by $\mathrm{CD}$ analyses. In addition, the ${ }^{13} \mathrm{C}-\mathrm{NMR}$ data of herbacetin 7-methyl ether was corrected by our group. The biological assay disclosed flavonoids exhibited potent antioxidant activity, but other phenylpropanoids, including the new compounds, showed weak antioxidant activity. Based on the antioxidant evaluation results of the isolated phenolic compounds, we think the various flavonoids are the major chemical constituents responsible for the anti-aging, life-span 
increasing and anti-radiation activities. To further evaluate the biological activity of these isolated phenols, the induction of IFN- $\gamma$ production was also evaluated because of its known immunoregulatory activity. As a result, four lignans (compounds 12, 13, 14 and 15) had the ability to induce IFN- $\gamma$ production as well as two flavonoid glycosides (compounds $\mathbf{8}$ and $\mathbf{9}$ ), moreover, the new compound $\mathbf{1}$ also possessed the inducing IFN- $\gamma$ production ability based on the cytokine assay. In all, the result of phytochemical investigation further reveals the chemical composition of $R$. crenulata and the biological evaluations of these compounds can provide insights into the various bioactivities of the chemical constituents of $R$. crenulata. As to the immunomodulatory effect of $R$. crenulata, polysaccharides of $R$. crenulata will be further investigated by our group to reveal the chemical basis of this activity.

\section{Supplementary Materials}

IR, HR-ESI-MS, ${ }^{1} \mathrm{H}-\mathrm{NMR},{ }^{13} \mathrm{C}-\mathrm{NMR}$, DEPT-135, ${ }^{1} \mathrm{H}-{ }^{1} \mathrm{H}$ COSY, HSQC, and HMBC spectra for compounds 1, 2, 11-13 can be accessed at: http://www.mdpi.com/1420-3049/20/08/13725/s1.

\section{Acknowledgments}

This work was supported financially by the National Natural Science Foundation (No. 81403059), Tianjin Applied Basic and Cutting-edge Technology Research Program (No. 13JCZDJC28600), National Science and Technology Major Projects for "Major New Drugs Innovation and Development" (2015ZX09J15102-004-004) and Tianjin City High School Science \& Technology Fund Planning Project (No. 20130202).

\section{Author Contributions}

J.-T.Z. fractionated the extract, isolated the compounds, elucidated structures and prepared the manuscript. C.-H.W. and M.-M.J. elucidated structures and prepared the manuscript. C.-Y.L. and X.-D.W. performed the bioassays. Y.Z., X.-M.G. and Y.-F.W. helped preparing the manuscript and provided discussion. H.-T.W. participated in its design and coordination and helped to draft the manuscript

\section{Conflicts of Interest}

The authors declare no conflict of interest.

\section{References}

1. Liu, S.; Wang, P.L.; Hu, Y.J.; Lan, X.Z.; Liao, Z.H.; Chen, M. Study on HPLC fingerprint of Rhodiola crenulata. J. Southwest Univ. Nat. Sci. Ed. 2014, 36, 215-221.

2. Chiu, T.F.; Chen, L.L.; Su, D.H.; Lo, H.Y.; Chen, C.H.; Wang, S.H.; Chen, W.L. Rhodiola crenulata extract for prevention of acute mountain sickness: A randomized, double-blind, placebo-controlled, crossover trial. BMC Complement. Altern. Med. 2013, 13, doi:10.1186/1472-6882-13-298.

3. Chu, Y.H.; Chen, C.J.; Wu, S.H.; Hsieh, J.F. Inhibition of xanthine oxidase by Rhodiola crenulata extracts and their phytochemicals. J. Agric. Food Chem. 2014, 62, 3742-3749.

4. Deng, S.G.; Yin, A.W.; Tian, R.; Li, T.F. The anti-aging effects of polysaccharides from Rhodiola crenulata. Chin. J. Gerontol. 2014, 67, 2161-2162. 
5. Chen, D.J.; Fan, J.T.; Wang, P.; Zhu, L.Y.; Jin, Y.; Peng, Y.; Du, S. Isolation, identification and antioxidative capacity of water-soluble phenylpropanoid compounds from Rhodiola crenulata. Food Chem. 2012, 134, 2126-2133.

6. Du, M.; Xie, J. Flavonol glycosides from Rhodiola crenulata. Phytochemistry 1995, 38, 809-810.

7. Jia, W.; Wang, C.; Wang, Y.; Pan, G.; Jiang, M.; Li, Z.; Zhu Y. Qualitative and quantitative analysis of the major constituents in Chinese medical preparation Lianhua-Qingwen capsule by UPLC-DAD-QTOF-MS. Sci. World J. 2015, 2015, doi:10.1155/2015/731765.

8. Li, T.; Ge, Z.L.; Zhang, H. Study on the chemical constituents of Rhodiola crenulata. West China Med. J. 2012, 27, 367-370.

9. Nakamura, S.; Li, X.Z.; Matsuda, H.; Yoshikawa, M. Bioactive constituents from Chinese natural medicines. XXVIII. Chemical structures of cyclic alcohol glycosides from the roots of Rhodiola crenulata. Chem. Pharm. Bull. 2008, 56, 536-540.

10. Yang, Y.N.; Liu, Z.Z.; Feng, Z.M.; Jiang, J.S.; Zhang, P.C. Lignans from the root of Rhodiola crenulata. J. Agric. Food Chem. 2012, 60, 964-972.

11. Cheng, X.F.; Lai, G.X. The immunomodulatory effect of Rhodiola crenulata. Chin. J. Ethnomed. Ethnopharm. 2013, 6, 24-25.

12. Darbinyan, V.; Kteyan, A.; Panossian, A.; Gabrielian, E.; Wikman, G.; Wagner, H. Rhodiola rosea in stress induced fatigue-a double blind crossover study of a standardized extract SHR-5 with a repeated low-dose regimen on the mental performance of healthy physicians during night duty. Phytomedicine 2000, 7, 365-371.

13. Jacob, R.; Nalini, G.; Chidambaranathan, N. Neuroprotective effect of Rhodiola rosea Linn against MPTP induced cognitive impairment and oxidative stress. Ann. Neurosci. 2013, 20, 47-51.

14. Pooja; Bawa, A.S.; Khanum, F. Anti-inflammatory activity of Rhodiola rosea - “A second-generation adaptogen". Phytother. Res. 2009, 23, 1099-1102.

15. Panossian, A.; Wikman, G.; Sarris, J. Rosen root (Rhodiola rosea): Traditional use, chemical composition, pharmacology and clinical efficacy. Phytomedicine 2010, 17, 481-493.

16. Nabiel, A.M.S.; Salwa, A.M.; Wafaa, M.M.A.; Kenneth, R.M.; Denis, B. Herbacetin and gossypetin 3-glucuronide-8-glucosides from Roemeria hybrid. Phytochemistry 1988, 27, 309-310.

17. Hussein, S.A.M.; Barakat, H.H.; Nawar, M.A.M.; Willuhn, G. Flavonoids from Ephedra aphylla. Phytochemistry 1997, 45, 1529-1532.

18. Na, C.S.; Hong, S.S.; Choi, Y.H.; Lee, Y.H.; Hong, S.H.; Lim, J.Y.; Kang, B.H.; Park, S.Y.; Lee, D. Neuroprotective effects of constituents of Eragrostis ferruginea against A $\beta$-induced toxicity in PC12 cells. Arch. Pharm. Res. 2010, 33, 999-1003.

19. Nguyen, P.H.; Yang, J.L.; Uddin, M.N.; Park, S.L.; Lim, S.I.; Jung, D.W.; Williams, D.R.; Oh, W.K. Protein tyrosine phosphatase 1B (PTP1B) inhibitors from Morinda citrifolia (Noni) and their insulin mimetic activity. J. Nat. Prod. 2013, 76, 2080-2087.

20. He, Z.Z.; Yan, J.F.; Song, Z.J.; Ye, F.; Liao, X.; Peng, S.L.; Ding, L.S. Chemical constituents from the aerial parts of Artemisia minor. J. Nat. Prod. 2009, 72, 1198-1201.

21. He, Z.Z.; Yan, J.F.; Liao, X.; Zhang, W.Y.; Ji, J.X.; Ding, L.S. A New Lignan and Its Application. Chinese Patent, No. CN 200910258342.2.2009-02-17, 17 February 2009.

22. Wang, X.M.; He, C.H.; Wang, X.L.; Hu, J.P.; Wang, X.Q.; Rena, K. Studies on the chemical constituents of Rhodiola rosea. J. Chin. Med. Mater. 2010, 33, 1252-1253. 
23. Lee, M.W.; Lee, Y.A.; Park, H.M.; Toh, S.H.; Lee, E.J.; Jang, H.D.; Kim, Y.H. Antioxidative phenolic compounds from the roots of Rhodiola sachalinensis A. Bor. Arch. Pharm. Res. 2000, 23, 455-458.

24. Zheng, R.R.; Ya, J.; Wang, W.J.; Yang, H.B.; Zhang, Q.W.; Zhang, X.Q., Ye, W.C. Chemical studies on roots of Ficus hirta. China J. Chin. Mater. Med. 2013, 38, 3696-3701.

25. Warashina, T.; Umehara, K.; Miyase, T. Flavonoid glycosides from Botrychium ternatum. Chem. Pharm. Bull. 2012, 60, 1561-1573.

26. Jutiviboonsuk, A.; Zhang, H.; Tan, G.T.; Ma, C.; van Hung, N.; Cuong, N.M.; Soejarto, D.D.; Bunyapraphatsara, N.; Fong, H.H.S. Bioactive constituents from roots of Bursera tonkinensis. Phytochemistry 2005, 66, 2745-2751.

27. Fu, Z.H.; Zhang, Y.M.; Tan, Y.M.; Tan, N.H.; Zhu, H.B.; Ji, C.J. Chemical constituents of Keteleeria evelyniana. Nat. Prod. Res. Dev. 2008, 20, 257-261.

28. Shang, X.Y.; Li, S.; Wang, Y.H.; Wang, S.J.; Yang, Y.C.; Shi, J.G. Chemical constitutents of Bauhinia aurea. China J. Chin. Mater. Med. 2006, 31, 1953-1955.

29. Chu, Y.H.; Wu, S.H.; Hsieh, J.F. Isolation and characterization of $\alpha$-glucosidase inhibitory constituents from Rhodiola crenulata. Food Res. Int. 2014, 57, 8-14.

30. Ding, A.H.; Nathan, C.F.; Stuehr, D.J. Release of reactive nitrogen intermediates and reactive oxygen intermediates from mouse peritoneal macrophages. Comparison of activating cytokines and evidence for independent production. J. Immunol. 1988, 141, 2407-2412.

31. Green, S.J.; Crawford, R.M.; Hockmeyer, J.T.; Meltzer, M.S.; Nacy, C.A. Leishmania major amastigotesinitiate the L-arginine-dependent killing mechanism in IFN- $\gamma$-stimulated macrophages by induction of tumor necrosis factor- $\alpha$. J. Immunol. 1990, 145, 4290-4297.

32. Sá-Nunes, A.; Faccioli, L.H.; Sforcin, J.M. Propolis: Lymphocyte proliferation and IFN- $\gamma$ production. J. Ethnopharmacol. 2003, 87, 93-97.

33. Sharma, O.P.; Bhat, T.K. DPPH antioxidant assay revisited. Food Chem. 2009, 113, 1202-1205.

34. Zhang, X.L.; Guo, Y.S.; Wang, C.H.; Li, G.Q.; Xu, J.J.; Chung, H.Y.; Ye, W.C.; Li, Y.L.; Wang, G.C. Phenolic compounds from Origanum vulgare and their antioxidant and antiviral activities. Food Chem. 2014, 152, 300-306.

35. Oliveira, C.M.; Ferreira, A.C.; de Pinho, P.G.; Silva, A.M. New qualitative approach in the characterization of antioxidants in white wines by antioxidant free radical scavenging and NMR techniques. J. Agric. Food Chem. 2008, 56, 10326-10331.

Sample Availability: Samples of the compounds 1-17 are available from the authors.

(C) 2015 by the authors; licensee MDPI, Basel, Switzerland. This article is an open access article distributed under the terms and conditions of the Creative Commons Attribution license (http://creativecommons.org/licenses/by/4.0/). 